\title{
PENGGUNAAN JUMPUTAN DAN TRITIK DALAM UPACARA ADAT DI SURAKARTA
}

\author{
Sarwono ${ }^{1}$, Adji Isworo Josef ${ }^{2}$, Tiwi Bina Afanti ${ }^{3}$, \\ Ratna Endah Santoso ${ }^{4}$, Novita Wahyuningsih ${ }^{5}$. \\ Fakultas Seni Rupa dan Desain, Universitas Sebelas Maret ${ }^{1,2,3,4,5}$ \\ sarwono59@staff.uns.ac.id ${ }^{1}$
}

\begin{abstract}
The Javanese society has a harmony concept which has become an interesting tradition part in live. The Javanese people, especially the Surakarta society, have a belief in the world philosophy (universe), consisting of the great universe ( macrocosmos) and small universe (microcosmos). The microcosmos cannot be separated from the great macrocosmos which must be kept its harmony with their lives, so the ritual elements of the small universe. Therefore, the art isi always connected with their lives, so the ritual elements consist in the traditional art. The art has three functions known in Javanese society, that is for a ritual purpose and a show purpose with entertaining characteristics for the inner satisfaction in the society. Moreover, the traditional artwhich is formed in the usage art, like the custom clothes, tools / instruments, ornaments and others functioning as ritual purposes, have definitely had the important value symbols in the society, or as the tools to support the ritual implementation in the society. The art of Tritik and Jumputan craft also contains the teachings of ethics and aesthetics in the form of visual appearances and symbolism of life which can basically lead humans to perfection and true identity.
\end{abstract}

Keywords: jumputan, tritik, the custom ceremony, traditional

\begin{abstract}
ABSTRAK
Masyarakat Jawa memiliki konsep keselarasan yang merupakan bagian tradisi yang penting dalam kehidupan. Orang Jawa, khususnya masyarakat Surakarta memiliki keyakinan dalam pandangan dunia (jagat), yang terdiri dari jagat gede (makrokosmos) dan jagat cilik (mikrokosmos). Mikrokosmos menjadi yang tidak terpisahkan dengan makrokosmos yang harus dijaga keselarasannya dengan unsur-unsur jagat cilik. Oleh sebab itu, seni selalu dikaitkan dengan kehidupannya, sehingga unsur ritual terdapat dalam seni tradisional. Kesenian memiliki tiga fungsi yang dikenal dalam masyarakat Jawa, yaitu untuk tujuan ritual, untuk tujuan tontonan yang bersifat entertaintment kepuasan batin dalam masyarakat. Apalagi kesenian tradisional yang berbentuk seni pakai, seperti pakaian adat, peralatan, hiasan, dan sebagainya dalam fungsinya sebagai kepentingan ritual, sudah barang tentu memiliki simbol-simbol yang bernilai dalam masyarakat, ataupun sebagai sarana untuk mendukung pelaksanaan ritual dalam masyarakat. Seni kerajinan tritik dan jumputan ini juga termuat ajaran etika dan keindahan yang berbentuk penampilan visual dan simbolisme hidup yang pada dasarnya dapat menuntun manusia menuju kesempurnaan dan jati diri yang sejati.
\end{abstract}

Kata kunci: jumputan, tritik, pakaian adat, tradisiona 


\section{PENDAHULUAN}

\section{A. Latar Belakang Masalah}

Karya seni kerajinan tritik dan jumputan dalam masyarakat merupakan sumber inspirasi yang tidak pernah habis digali dan dikembangkan nilai-nilainya. Seni tritik dan jumputan ini menempatkan diri pada khasanah budaya masyarakat sejak dahulu kala diadakan secara turun temurun yang merupakan bagian dari pengetahuan tradisional (traditional knowledge) sekaligus merupakan karya intelektual masyarakat.

Seni kerajinan tritik dan jumputan ini juga termuat ajaran etika dan keindahan yang berbentuk penampilan visual dan simbolisme hidup yang pada dasarnya dapat menuntun manusia menuju kesempurnaan dan jati diri yang sejati. Kaidah ini dimungkinkan, mengingat bahwa seni tersebut merupakan pengejawantahan jiwa dalam kehidupan yang selalu mewujudkan aksi dan reaksi serta secara kontinyu untuk mendapatkan penyelesaian masalah yang bijak dan baik sesuai kultur yang telah terbentuk. Seni tersebut merupakan bagian dari keseluruhan ekspresi budaya mayarakat, sebagai karya pengetahuan tradisional. Hal ini juga merupakan hasil buah pikir manusia yang dimulai sejak dahulu, yang perkembangannya merupakan kekayaan intelektual. Dengan demikian, muncul masalah perlindungan dan pengembangannya dalam masyarakat. Sehubungan dengan kegiatan perekonomian masyarakat, yang seni tradisional dapat terkait dengan kegiatan ekonomi kreatif, maka kepemilikan dan kegiatan ekonomi tersebut dalam perkembangannya menjadi bagian tidak terpisahkan dengan kegiatan ekonomi global.

Kajian penelitian ini, secara ringkasnya yang menjadi subyek penelitian menyangkut: 1) karya kerajinan tritik dan jumputan yang merupakan "traditional knowledge" mengandung nilai-nilai budaya masyarakat, 2) makna simbol dalam seni tritik dan jumputan yang mencerminakan nilai-nilai budaya, 3) dasar- dasar pengembangan desain, dan 4) kebijakan pemerintah (pusat maupun daerah) untuk memberikan perlindungan seni kerajinan tritik dan jumputan sebagai karya seni yang merupakan kreasi budaya tradisional. Bersamaan dengan ini, pengkajian dilandasi kerangka pikir hukum dan budaya, hingga memperoleh pemahaman nilai-nilai yang terkandung dalam norma hukum. Dengan begitu, pendekatan budaya menjadi penting untuk pemberlakuan hukum dalam masyarakat. Hal ini berkaitan dengan pendekatan 
teoritik sistem hukum yang terdiri dari subtansial, struktural, dan budaya.

Dalam rangka perlindungan dan mengembangkannya memerlukan data base karya-karya yang disusun secara sistematik sebagai seni kerajinan tritik dan jumputan yang berada di wilayah Surakarta. Dengan demikian dapat diketahui karakteristik yang didasarkan pada kekhasan, keunikan dan historis pada seni kerajian tritik dan jumputan tersebut yang merupakan kekayaan "traditional knowledge" sebagai kekayaan budaya bangsa yang secara keseluruhan bersama dengan budaya-budaya lokal daerah-daerah lain. Mengkaji hal ini berhubungan dengan kajian hukum sebagai norma yang mengatur kepentingan individu maupun masyarakat agar terlindungi dan sejalan dengan program pembangunan. Oleh karena itu, perhatian konsep teoritik dalam pengembangan desain menjadi strategis terhadap potensi pengembangan seni kerajinan tritik dan jumputan sesuai dengan tuntutan global namun tidak bertentangan dengan nilai-nilai budaya masyarakat. Demikian pula pengembangan teori di bidang kebijakan dalam pemerintahan untuk melindungi perwujudan "traditional knowledge", khususnya seni kerajinan tritik dan jumputan sebagai asset budaya dan ekonomi daerah, yang mengandung kekayaan kearifan lokal sekaligus dapat dijadikan kapital sosial untuk membangun dunia kerajinan masyarakat yang lebih terbuka serta bertanggung jawab sesuai akar budaya masyarakat. Traditional knowledge berupa seni kerajinan tritik dan jumputan merupakan hasil karya budaya yang penuh dengan nilai-nilai dan simbol budaya dalam kehidupan masyarakat Jawa khususnya Surakarta.

\section{B. Tinjauan Pustaka}

\section{Seni Kerajinan Jumputan, Tritik Tradisional}

Pengembangan motif kain tritik dan jumputan di Surakarta sampai saat ini disesuaikan dengan permintaan pasar dengan tetap mempertahankan ciri motif sesuai dengan desain yang dimiliki. Pada dasarnya motif-motif tradisi termasuk juga batik dibuat dengan sumber ide dari bentuk motif flora dan bentuk geometri atau komposisi tata warna, sedang bentuk fauna (dunia hewan) jarang atau bahkan tidak dihadirkan sama sekali, dan sampai saat ini masih dipertahankan (Sarwono, 2016).

Pengembangan kain tritik dan jumputan tradisional mempunyai peranan penting di dalam penggunaannya. Pada jaman dahulu tenun ikat dipakai sebagai piranti dalam upacara adat dan sebagainya. Tetapi sekarang dengan adanya pergeseran waktu serta jaman, penggunaan yang khusus tersebut mulai berangsur-angsur berubah. Hal ini 
disebabkan para perajin lebih bersifat komersial, sehingga kain tenun ikat dalam penggunaannya sudah menjadi barang ekonomis yang komersial.

Budayaan Jawa tidak dapat terlepas dari nilai - nilai falsafah, baik kejiwaan maupun pola pikirnya. Landasan inilah dalam berbagai pembahasan kebudayaan kejiwaan Jawa disebut "Kejawen" (Suseno, 2001: 11-15). Sedang dalam unsur-unsur kebudayaan Jawa dapat meliputi kesusasteraan, sistem mata pencaharian, sistem kekerabatan, pola-pola menetap dan arsitekturnya, tata upacara, juga keseniannya.Titik berat yang melatar belakangi kejawen adalah disebut "ngilmu", sehingga ilmu kejawen dapat menembus dan lingkungannya yang sempit menuju sifat- sifat umum dan universal. (Holt dalam Soedarsono, 2000:155). Walaupun berlokasi yang sempit dan khusus yaitu Jawa, tetapi kebudayaan tersebut jauh menerawang dalam hidup dan kehidupan alam kemanusiaan. Dengan tujuan kebenaran dan kesempurnaan yang terkandung dalam kebudayaan Jawa yang bersifat falsafah itu terletak pada nilai-nilai simbolisme yang muncul akibat adanya kontak antara manusia dengan mikro kosmos dan makro kosmos, antara kehidupan lahir dan kehidupan batinnya. Apabila dilihat dalam kebudayaan Jawa khususnya unsur kejiwaan, maka terdapat suatu usaha atau ikhtiar untuk menjadikan manusia yang berbudi luhur dan suci dalam segala sikap batin dan tingkah lakunya. Budi luhur dan kesucian sikap batin serta tingkah laku merupakan nilai yang erat hubungannya dengan kehidupan lahir dan batin. Juga nilai-nilai tersebut timbul dikarenakan adanya hubungan antara hubungan manusia dengan Sang Hyang Illahi yang bersifat universal (Buchari S., 2005:2 - 5). Kebudayaan Jawa dapat dilihat dari adanya keseimbangan antara hati nurani yang berinteraksi dengan alam dan Sang Hyang Pencipta yang di -landasi penalaran yang timbul dari intelektual dalam materi "ngelmu". Hati nurani, superitual manusia, dan intelektualitas bersambungan dengan Sang Hyang Pencipta. Dengan demikian ketiganya selalu berhubungan dengan eratnya. Keseimbangan tersebut dapat dilihat dalam karya - karya seninya, di antaranya seni pewayangan dengan berbagai wiracarita yang kesemuanya mengandung nilai-nilai falsafah yang termuat dalam simbolisme-simbolisme. Dengan maksud segala perbuatan manusia harus selalu mencari keseimbangan antara manusia dan alam, serta mencari kesempurnaan hidup dan kehidupannya (Mulder, 2006: 16-19). Masyarakat sering mengistilahkan rancu istilah simbol dan simbolisme. Hal ini disebabkan keduanya diterjemahkan dengan istilah yang sama yaitu "lambang". Simbolisme merupakan 
simbol-simbol yang digunakan baik dalam bidang seni maupun yang lainnya, terutama untuk memberi tanda khusus pada benda atau dengan mensugestikan melalui imajiimaji inderawi benda tersebut yang tidak dapat dilihat oleh inderawi. Sebagai contoh penggunaan kain jumputam tritik klasik oleh seseorang yang disucikan atau dimuliakan, untuk menunjukkan kualita, kekuatan atau derajatnya. Menurut pendapat Read, dinyatakan simbolisme dapat saja berbentuk karya seni yang unsur-unsur pendukungnya menggambarkan analogi nilai - nilai dari karakter tertentu yang mewakili idea abstrak. Nilai-nilai ide abstrak itu akan membentuk kesatuan atau gestalte hubungan kualita, kekuatan dan derajat (Read, 1970:121-130).

Karya seni klasik, memuat dan memenuhi unsur-unsur diatas, karena seni jumputan tritik klasik diciptakan dalam kesatuan kualita, kekuatan dan derajat pada waktu itu yaitu sebagai benda seni untuk melegitimasi kedudukan dan keberadaan kerajaan sebagai penguasa (Soedarmono, 1990: 10).

Setiap penciptaan motif pada mulanya selalu diciptakan dengan makna simbolisme dalam falsafah Jawa. Sehingga pada waktu itu tidak sembarang orang dapat memakai dan biasanya pemakaian motif didasarkan atas kedudukan sosial seseorang di dalam masyarakat. karena apabila ada seseorang melanggarnya, maka akan dikenakan hukuman. Dan maksud dari usaha penciptaan motif jumputam tritik pada zaman itu agar memberi kesejahteraan dan kemuliaan serta memberi status sosial bagi si pemakainya. Motif tersebut dinamakan motif larangan, namun dewasa ini telah menjadi milik masyarakat. Walaupun demikian tata cara pemakaian pada upacara-upacara adat yang resmi di kalangan kraton masih diperhatikan.

Motif tritik dan jumputan sangat bervariasi, maka dalam pemakaiannya harus disesuaikan dengan tata cara dan adat istiadat yang berlaku pada zaman itu. Karena pada ha kekatnya tiap-tiap pemberian nama motif tritik dan jumputan mempunyai makna simbolisme tertentu. Mengingat di dalam penciptaan motif tritik dan jumputan pada zaman dahulu tidak hanya indah semata, melainkan juga memberi makna yang erat hubungannya dengan falsafah hidup dan kehidupan pada masyarakatnya.

Motif tritik dan jumputan, selain unsur motifnya mengandung makna falsafah yang tinggi juga unsur warna yang ada dalam motif tersebut memiliki nilai-nilai falsafah. Memahami simbolisme dalam visualisasi tatawarna motif jumputam tritiknya, sesungguhnya terkandung nilai-nilai falsafah orang Jawa yang dibentuk menurut kerangka kultur yang religius-magis. Dalam kaitannya dengan seni jumputam tritik klasik, pemakaian tatawarna 
kuning, putih, merah (soga), biru, hitam menjadi karakteristik masyarakat Jawa yang di anggap memiliki lambang-lambang pemujaan terhadap "causa prima" yang berada dalam kedudukan tertinggi. Pada mulanya simbolisme tersebut dinyatakan lewat pralampita atau pralambang. Warna dasar dalam motif jumputam tritik klasik tersebut diatas, nam paknya diilhami oleh lambang-lambang warna dalam kosmologi Jawa, yaitu "keblat papat lima pancer" (Kartosoedjono, 1950: 14 -23).

Makna-makna tersebut, di mana tiap - tiap mata angin memiliki nilai warna simbolik, misalnya: arah timur $=$ hitam, arah selatan $=$ merah, arah barat $=$ kuning dan arah utara $=$ putih. Warna lain yang merupakan perpaduan dari empat warna di atas dan berada di tengah-tengah sebagai bagian yang kelima atau "lima pancer". Masing-masing warna itu rupanya juga memiliki nilai perwataan sendiri yang dijabarkan dalam ajaran Tasawuf Jawa, dikenal sebagai "sederek sekawan gangsal pancer", yaitu: bumi, dilambangkan warna hitam yang memiliki watak luwamah, api dilambangkan warna merah yang memiliki watak amarah, angin dilambangkan warna kuning yang memiliki watak supiyah, air dilambangkan warna putih yang memiliki watak mutmainah dan pusatnya adalah manusia yang dilambangkan banyak warna, sehingga setiap manusia memiliki empat watak tersebut (Soetarno, 2002: 27 - 28).

Upacara adat merupakan suatu suatu hal yang sangat universal, karena upacara tersebut terdapat di seluruh dunia dengan berbagai cara atau adat yang berbeda-beda. Orang yang telah melakukan upacaea adat perkawinan misalnya, memiliki makna bahwa mereka telah melakukan hidup baru, yaitu membina hidup berumah tangga. maka perkawinan seringkali dimulai dengan berbagai upacara untuk menyongsong dalam kehidupan baru nanti dapat selamat, bahagia, sejahtera, tanpa ada suatu hal yang merintangi baik dimulai dari pelaksanaan perkawinan sampai menjalani kehidupan baru.

Di berbagai daerah memiliki tata cara atau adat sendiri dalam melaksanakan upacara perkawinan. Juga rententan acara perkawinan memiliki ciri khas sendiri dengan berbagai perlengkapan upacaranya. Dari berbagai rentetan upacara perkawinan akad nikah inilah yang paling penting dalam penyelenggaraannya, karena dalam upacara tersebut peristiwa yang sangat penting terjadi. Kedua pengantin saling berjanji untuk hidup bersama, sedang upacara lain sebagai persyaratan adat untuk menunjang terlaksananya perhelatan tersebut (M. Harjowirogo, 1979: 42).

Upacara perkawinan sebagai salah satu contohnya, menurut hukum adat Jawa 
ada tata cara tersendiri, yaitu dimulai dengan berbagai upacara sebagai simbolisme dari berbagai rentetan upacaranya. Menurut Tiknopranoto bahwa upacara adat perkawinan Jawa di Surakarta biasanya calon mantu (temanten pria) pada waktu melamar harus memiliki kriteria bobot, bibit dan bebet (tanpa th.: 41). Lebih lanjut ia menerangkan bahwa yang dimaksud bobot adalah keadaan calon menantu tentang ilmu pengetahuan, kedudukan serta kekayaan atau penghasilan yang sangat diperlukan untuk menunjang kebutuhan dan kelstarian hidup berkeluarga. Bibit dimaksudkan adalah asal usul atau keturunan calon menantu dari mana berasal, sedang bebet memiliki makna tentang naluri atau kelakuan yang baik, sehingga dapat memberi keturunan anak yang berbudi luhur.

Tritik dan jumputan memiliki pola-pola yang diciptakan dengan latar belakang falsafat hidup orang Jawa, ternyata ada pola diciptakan khusus untuk dipakai oleh orang tua untuk menuntun anaknya dalam prosesi perkawinan tersebut. Pola tersebut di antaranya: bermotif Sindur. Hal ini disebabkan karena selain corak polanya yang sangat indah, juga didalamnya terkandung makna simbolis yang merupakan ungkapan serta harapan akan kebahagiaan, kesejahteraan, kemuliaan dalam menjalankan hidup, serta terhindar dari hal-hal yang kurang baik dalam melaksanakan upacara adat. Harapan serta doa tersebut terpancang di dalam ornamen-ornamen motif pada motif tritik dan jumputan.

\section{Jumputan Tritik}

Kain-kain tradisional Indonesia saat ini telah dikenal secara meluas oleh tidak hanya masyarakat Indonesia tetapi juga dunia. Setiap daerah di Indonesia mempunyai kain tradisional yang mencirikan keunikan budaya daerah tersebut dengan teknik pembuatan kain yang berbeda pada setiap daerahnya. Teknik tritik dan jumputan merupakan salah satu teknik tekstil yang digunakan untuk membuat motif pada beberapa kain tradisional Indonesia. Kain tritik jumputan dipilih menjadi objek penelitian melihat perkembangan desain motif pada kain tritik jumputan yang sudah dilakukan dan masih mempunyai potensi yang besar untuk dikembangkan (Putri, 2017: 39).

Kain tritik jumputan merupakan kain tradisional yang pada awalnya tidak digunakan secara bebas karena dianggap sebagai obat untuk menyembuhkan berbagai macam penyakit. Ciri khas motif kain tritik jumputan yang selama ini dibuat adalah kombinasi dari motif garis tidak beraturan berjumlah dua atau tiga garis dan motif figuratif 
yang dikomposisikan secara vertikal. Di samping corak dan warna tradisional yang sudah baku, saat ini terlihat pula corak yang baku dengan permainan nuansa yang lebih beragam, mengikuti selera yang berlaku pada saat ini. Pengembangan juga dilakukan dengan membuat ragam hias baru pada motif kain tritik jumputan. Motif dibuat dengan cara menghias kain putih di mana pola hiasan dijelujur dengan benang lalu ditarik eraterat sebelum dicelup, setelah kering benang dilepaskan dan timbulah motif-motif putih atas dasar bewarna. Pada teknis pengerjaannya, teknik tritik melalui 4 proses yaitu proses penggambaran pola di atas kain, proses penjahitan jelujur, proses penarikan/pengerutan, dan proses pewarnaan/pencelupa (Titisari dkk., 2014: 131). Proses penggambaran pola dan proses penjahitan jelujur merupakan proses yang menentukan seberapa besar area perintang yang nantinya akan menghasilkan motif. Area perintang terbentuk dari kerutan yang disebabkan karena adanya jahitan yang ditarik lalu diikat, dimana besar dan bentuk kerutan tersebut ditentukan oleh jarak dan pola jahitan. Hingga kini, pembuatan pola pada teknik tritik (khususnya di kain tritik jumputan) belum memperhatikan ketentuan pada jarak dan pola jahitan sehingga berpengaruh terhadap motif yang dihasilkan.

\section{Metode Penelitian}

Penelitian berlokasi di wilayah Surakarta. Ini sebenarnya merupakan suatu intgrasi secara kultural yang dulu berasal dari kultur Surakarta, yang sekarang ini wilayah Surakarta sebagai pengertian secara administratif, terhubung dengan wilayah di luarnya.

Berdasarkan masalah yang diteliti, bentuk penelitian yang di pakai studi kasus tunggal. Studi kasus tunggal merupakan studi kasus terpancang yang memusatkan pada beberapa kemungkinan yang telah ditentukan sebelum peneliti terjun ke lapangan studinya. Sedangkan pedekatan hukum dilihat dalam realitasnya bukan hanya sebagai norma-norma desain tekstil.

Sumber Data berupa karya seni tritik dan jumputan di Surakarta dan sekitarnya, Informan yang terdiri: Para seniman tritik dan jumputan, baik yang profesional, akademik maupun seniman yang tahu tentang masalah tersebut, Arsip dan dokumen serta catatan yang diperoleh dari berbagai pihak yang dapat menunjang penelitian ini, seperti catatan tentang tritik dan jumputan. Teknik Pengumpulan data berupa wawancara yang bersifat "open - ended" dan mendalam, dalam penelitian kualitatif sering disebut indepth interviewing.

Observasi dapat dilakukan secara langsung atau juga sering disebut observasi 
partisipasi pasif. Dalam observasi ini, peneliti hanya sebagai pengamat tanpa terlihat peran apapun. Dokumen dan arsip merupakan sumber data yang penting, juga artinya dalam penelitian kualitatif terutama sasaran penelitiannya pada latar belakang atau berbagai peristiwa yang terjadi dimasa lampau dan sangat berkaitan dengan kondisi peristiwa masa kini yang sedang di teliti. Oleh karena itu cuplikan yang digunakan lebih bersifat "purposive sampling" atau tepatnya merupakan cuplikan dengan "criteriation based selection". Peneliti memilih informan yang dipandang paling mengetahui permasalahan untuk memperoleh data. Cara untuk meningkatkan keabsahan data dalam penelitiannya, yaitu dengan "triangulasi data". Cara triangulasi data dimaksud bahwa dalam penelitian menggunakan berbagai sumber data yang berbeda untuk mengkumpulkan data yang sejenis atau sama, sehingga validitas data dapat terjamin (Sutopo, 2000, 27-30). Proses analisis dalam penelitian ini terdapat tiga komponen utama yang harus benar-benar dilakukan, yaitu reduksi data, sajian data dan penarikan kesimpulan atau verifikasi.

\section{HASIL DAN PEMBAHASAN}

Pemakaian kain dodot adalah dengan melilitkan kain mulai dada hingga ke kaki, yang memiliki lebar dan panjang tidak layaknya kain panjang terbuat dari bahan katun yang memiliki sifat mudah menyerap air dan tahan lama (awet). Warnanya biru tua dengan motif kaligrafi Allah Hu Hu yang di tuliskan diatas kain dengan teknik prada, dan ornamen hias berupa lekukan-lekukan garis. Motif ini tidak terlepas prinsip desain yang terdiri dari kesatuan, keseimbangan, dan keselarasan. Di tengah-tengah kain terdapat motif Blumbangan yang dibuat dengan teknik Tritik. Unsur dominannya tulisan kaligrafi Allah $\mathrm{Hu} H u$ yang merupakan pusat perhatian, dan dianggap memiliki suatu kekuatan. Dalam kostum tari Bedhaya Anglir Mendhung ini yang termasuk warna bangun tuka, slawir dari dodot, bunga rajut melati, buntal dan anak panah. Kesemuanya tertata secara indah, di sinilah letak nilai seninya dan penggunaannya mengandung arti. Pada penataan dodot bagian belakang dibentuk draperi atau lipatan-lipatan, karena letaknya dipantat disebut bokongan sebagai lambang manusia dalam kehidupannya harus memiliki dasar sehingga tidak goyah. Terdapat pula Songkokan yaitu lekukan yang menonjol bertempat di bagian belakang kanan atas bokong, yang bermakna dalam kehidupan supaya manusia menyisihkan penghasilannya sebagai bekal persediaan.

Motif blumbangan adalah bentuk belah ketupat yang terdapat di tengah dodot yang dipakai di Puro Mangkunegaran berwarna putih yang artinya air, yang mengandung 
makna memberikan kesuburan dan kehidupan, agar hidup tentram, makmur, dan subur. Selain itu dalam blumbangan juga terdapat lekukan naik turun yang disebut ombak, yang menggambarkan dalam kehidupan manusia terkadang berada di atas dan kadang di bawah sehingga diharapkan manusia siap menghadapinya.

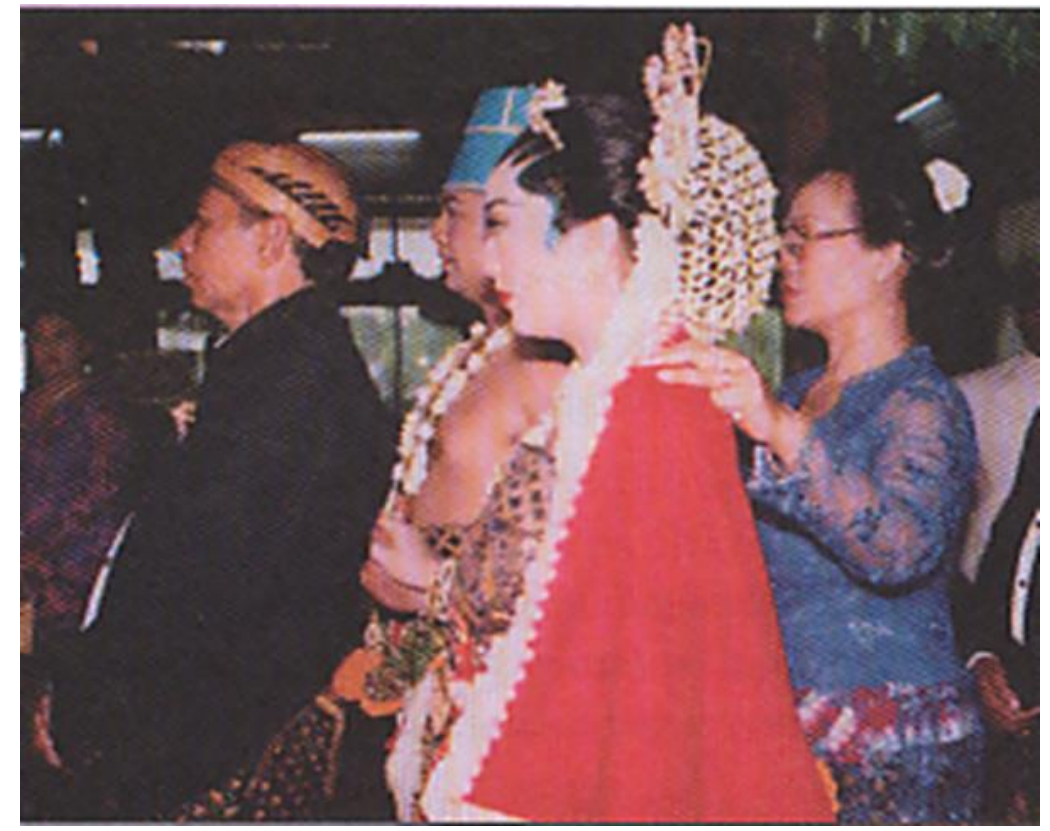

Gambar 1. Penggunaan kain jumputan dan tritik pada pakaian adat pengantin dodot dalam upacara adat perkawinan. Dokumentasi. Sarwono:2002

Kain jumputan dan tritik pada dodot nampak dipakai dalam upacara perkawinan (gambar 1). Kain yang dipakai bernilai seni yang menunjukkan keceriaan dalam kesenangan. Namun tidak boleh melupakan kehidupan selanjutnya dalam menjalani perkawinan, tidak boros dan selalu mempersiapkan masa depan. Dalam kehidupan perkawinan selalu ada cobaan dan ujian, namun harus tetap tidak goyah. Motif kain Sindur yang dibuat sebagai bahan untuk selendang (pakaian adat Jawa) biasanya dipakai dalam upacara adat perkawinan. Bahannya katun, dan memiliki sifat mudah menyerap air dan tahan lama. Warnanya merah dan putih yang dibuat di atas kain dengan teknik jumputan dan tritik, sehingga tidak merata dikarenakan efek teknik tersebut.

Memahami simbolisme dalam visualisasi tatawarna motif kain tritik dan jumputan terkandung nilai-nilai falsafah orang Jawa yang dibentuk menurut kerangka kultur yang religius-magis. Dalam kaitannya dengan seni klasik, pemakaian tatawarna kuning, putih, merah (soga), biru, hitam menjadi karakteristik masyarakat Jawa yang dianggap memiliki 
lambang-lambang pemujaan terhadap"causa prima" yang berada dalam kedudukan tertinggi. Pada mulanya simbolisme tersebut dinyatakan lewat simbol. Warna dasar dalam motif klasik tersebut diilhami oleh lambang-lambang warna dalam kosmologi Jawa yang mengajarkan pada tiap penjuru mata angin memiliki makna warna simbolik, misalnya: selatan $=$ merah, utara $=$ putih. Warna lain yang merupakan perpaduan dari dua warna di atas. Kelima warna itu juga memiliki nilai ajaran Tasawuf Jawa, yaitu: api lambang warna merah yang mencerminkan watak keberanian, keberanian bagi orang tua untuk menikahkan anaknya serta keberanian anak untuk menempuh hidup baru yang banyak tantangan yang akan dihadapi, air lambang warna putih yang memiliki watak mutmainah dalam hitungan pasaran warna ini sebagai simbol ketulusan bagi orang tua untuk menikahkan anaknya serta kesucian cinta kedua pengantin untuk menempuh hidup baru yang akan banyak menghadapi ujian hidup.

Motif Kain Pare Anom dengan komposisi warna dasar hijau dan kuning. Arti istilah pare anom, berasal dari arti kata pare adalah buah yang rasanya pahit dan sering dijadikan bahan untuk masakan khas Jawa, sedang anom artinya muda, sehingga memiliki makna kepahitan atau keprihatinan. Dalam berjuang mengarungi hidup ini, kalau dulu berjuang mengusir penjajah, diharuskan untuk prihatin. Sehingga pengertian ini memiliki makna simbolisme keprihatinan untuk tetap berjuang, dan mendapatkan keselamatan dalam segala kegiatan atau upacara adat. Motif Kain Kemben Bangun Tulak digunakan untuk kembenan yakni kainnya dililitkan pada perut memutar sampai habis, fungsinya mengikat dan memperkuat pemakaian kain atau sarungan agar tidak melorot. Warna kain dodot menggambarkan situasi peperangan dan sesuai dengan warna bendera pangeran Samber Nyawa (Mangkunegara I). Warna bangun tulak adalah warna warna-warna gelap yang menggambarkan keprihatinan.

Kain kemben bangun tulak ini dipakai calon pengantin putri dalam upacara adat jawa untuk tatacara "siraman", dengan nyamping kemben "bangun tulak', komposisi warna dasarnya biru kehitam-hitaman dengan motif blumbangan warna putih. Ini memiliki makna simbolisme untuk menjauhkan dari sing alus (makluk halus) sing kasar (jahat), serta mendekatkan para leluhurnya untuk senantiasa melindungi hidupnya, sehingga pengantin terhindar dari mara bahaya, dan kelak hidupnya akan bahagia. Makna simbolis yang terkandung pada seni tritik dan jumputan dalam upacara adat Jawa berhubungan dengan pandangan orang Jawa melihat setiap manusia sebagai bagian kecil dari dunia sosial-alamiah yang lebih luas. Karena itu ketentuan mengenai kehidupan sosial dengan 
sendirinya mengikuti keniscayaan metafisik. Tatanan kehidupan sosial merupakan suatu tatanan yang telah baku karena merupakan bagian dari tertib alam seluruhnya, yang bersifat misterius sebagaimana tampak dalam beberapa aspeknya yang bersifat teratur dan tidak beruba-ubah. Dalam hal ini, kegiatan-kegiatan hidup orang Jawa selalu diliputi aspek keteraturan yang memasuki kehidupan individual maupun komunal, sehingga karya-karya tradisi juga bersifat teratur. Karakter semacam ini dapat dikesankan bagi orang luar sebagai apa adanya, lugu, dan cenderung sebagai hal yang dinilai statis, tidak berubah-ubah, bahkan hingga secara turun temurun. Akan tetapi memang inilah yang menjadi ciri dari pengetahuan tradisional. Kerangka pandangan orang Jawa memandang setiap manusia bagian dari dunia yang lebih luas tak terlepas dari sifat metafisik, karya seni tradisional jumputan dan tritik wujud cerminan tersebut, dalam hal pemaknaan arti simbol-simbol budaya yang terkandung dalam seni tritik dan jumputan. Seni kerajinan tritik dan jumputan dimanfaatkan dalam upacara-upacara adat, seperti: perkawinan, perayaan-perayaan, menempati rumah baru, yang berfungsi untuk menolak bala (menghindari kejahatan/mencegah terjadinya musibah). Seni ini diwujudkan dalam pakaian adat yang mengandung makna simbolis, yang menjadi keyakinan sebagian orang Jawa. Kehidupan masyarakat terkandung konsep keselarasan yang merupakan konsep tradisi yang penting dan mendasar. Khususnya, orang Jawa melihat dirinya berada dalam pandangan dunia (jagat), yang terdiri dari jagat gede (makrokosmos) dan jagat cilik (mikrokosmos), jagat cilik merupakan bagian dari jagat gede yang harus dijaga keselrasannya dengan unsur-unsur jagat cilik. Oleh karena itu, seni memang selalu, apalagi seni tradisional mengandung unsur ritual. Kesenian pada umumnya memiliki tiga fungsi yang selama ini dikenal dalam masyarakat, yaitu untuk kepentingan ritual, untuk kepentingan festival, dan sebagai tontonan yang bersifat entertaintment kepuasan batin. Apabila kesenian itu berbentuk rupa seni terpakai, seperti busana, peralatan, hiasan, dan sebagainya dalam fungsinya sebagai kepentingan ritual tentu saja memiliki simbolsimbol yang bernilai ritual, ataupun sebagai sarana yang mendukung pelaksanaan ritual tersebut

Konsep keselarasan dalam kultur Jawa di dalamnya terdapat nilai jatmika dan edi-peni untuk memahami budaya orang Jawa. Jatmika dapat diartikan sebagai simpatik, menarik, ramah. Orang Jawa dididik untuk menghindari konflik (karena konflik akan merusak hubungan yang laras) akan sealalu berusaha menjaga agar dalam 
berhubungan dengan sesama manusia untuk sealalu bersikap jatmika. Sikap ini akan terlebih dulu diutamakan, baru kemudian bersikap hormat bila berhadapan dengan orang yang dituakan, yang lebih senior, yang berkedudukan lebih tinggi, atau orang asing. Sikap jatmika semacam teknik yang memungkinkan keselarasan selalu dapat terjaga. Kemudian, sikap edi-peni yang berarti indah dak apik seringkali disejajarkan dengan nilai adiluhung yang berarti indah dan mulia. Nilai edi-peni dan adiluhung dikembangkan sebagai nilai yang penting, yang meliputi hampir semua segi kehidupan, sehingga tidak hanya menyangkut kesenian melainkan pada semua penampilan sikap. Nilai edi-peni ini dalam karya seni sebagai estetika atau aspek keindahan termasuk pada seni jumputan dan tritik.

\section{SIMPULAN}

Jenis-jenis motif tritik dan jumputan sebagai seni kerajinan di wilayah Surakarta motif kain dodot yang dililitkan mulai dada hingga ke kaki, penataannya dibentuk bokongan, dan Songkokan. Terdapat motif dodot blumbangan. Motif sindur merupakan kain yang dibuat sebagai bahan untuk selendang (pakaian adat Jawa), Motif pare anom untuk umbul-umbul, yang komposisi warnanya dasar hijau dan kuning. Motif kain kemben bangun tulak. Motif kain selendang umumnya pada pakaian kebaya oleh kaum perempuan. Motif kain selendang untuk melengkapi dalam busana adat, dengan warna motifnya sangat bervariasi dan sangat menarik. Motif kain kebaya merupakan pakaian adat Jawa, Proses pembuatan seni kerajinan tritik dan jumputan tersebut dengan Teknik Ikat Celup dan Teknik Perintang. Pewarnaan dengan cara pencelupan kain ke dalam zat warna dan perintangan dengan menggunakan teknik jahit jelujur yang ditarik kencang hingga mampat dan padat sehingga bisa digunakan sebagai perintang warna masuk dalam serat kain. Pada dasarnya prinsip dari ikat celup adalah menggunakan bahanbahan perintang untuk menghalangi masuknya zat warna pada kain yang dirintangi. Ada tiga golongan dalam perintangan warna yaitu teknik ikatan, tritik (jelujur), dan bundelan.

Variasi bentuk juga dapat dilakukan dengan cara memadukan dua atau lebih teknik perintangan dalam satu kain yang sama. Termasuk didalamnya; jumputan, remasan (efek marmer), dan lipatan. Makna simbolis yang terkandung pada motif seni tritik dan jumputan dalam upacara adat Jawa di wilayah Surakarta, sebagaimana terkandung dalam kain dodot yang berwarna biru tua dengan motif kaligrafi $\mathrm{Allah} \mathrm{Hu} \mathrm{Hu}$ yang dituliskan di atas kain dengan teknik prada. Di tengah - tengah kain terdapat motif 
Blumbangan yang dibuat dengan teknik Tritik. Simbolisme sesungguhnya terkandung nilai-nilai falsafah orang Jawa yang dibentuk menurut kerangka kultur yang religius magis. Pemakaian tatawarna kuning, putih, merah (soga), biru, hitam menjadi karakteristik masyarakat Jawa yang dianggap memiliki lambang-lambang pemujaan terhadap "causa prima", sebagai pralampita atau pralambang (simbol) berdasarkan warna dalam kosmologi, yaitu “keblat papat lima pancer". Di tiap-tiap mata angin memiliki makna warna simbolik, yaitu arah timur $=$ hitam, selatan $=$ merah, barat $=$ kuning dan utara $=$ putih.

Warna lain yang merupakan perpaduan dari empat warna di atas dan berada di tengah-tengah sebagai bagian yang kelima atau "lima pancer". Kelima warna itu juga memiliki nilai perwataan sendiri yang dijabarkan dalam ajaran Tasawuf Jawa, dikenal sebagai "sederek sekawan gangsal pancer", yaitu: bumi, lambang warna hitam yang memiliki watak luwamah dalam hitungan pasaran warna ini sebagai simbol "legi", api lambang warna merah yang memiliki watak amarah dalam hitungan pasaran warna ini sebagai simbol "wage", angin lambang warna kuning yang memiliki watak supiyah dalam hitungan pasaran warna ini sebagai simbol "kliwon", air lambang warna putih yang memiliki watak mutmainah dalam hitungan pasaran warna ini sebagai simbol "pon" dan pusatnya adalah manusia yang lambang banyak warna dalam hitungan pasaran warna ini sebagai simbol "pahing", sehingga setiap manusia memiliki empat watak tersebut. Kain dodot yang penataannya bokongan ataupun Songkokan mempunyai makna dalam kehidupan supaya manusia menyisihkan penghasilannya sebagai bekal persediaan, dalam kehidupannya tidak dilakukan hidup boros, harus hidup hemat. Penataan berbentuk blumbangan berwarna putih yang menyimbolkan air, berarti di dalam kehidupan di tengahnya terdapat air yang dapat memberikan kesuburan dan kehidupan, juga agar hidup tentram, makmur, dan subur.

Selain itu dalam blumbangan juga terdapat lekukan naik turun yang disebut ombak, yang menggambarkan kehidupan manusia yang kadang berada di atas dan kadang di bawah, supaya manusia siap menghadapinya. Warna kain dodot menggambarkan situasi peperangan dan sesuai dengan warna bendera pangeran Samber Nyawa (Mangkunegara I). Warna bangun tulak adalah warna warna-warna gelap yang menggambarkan keprihatinan. Calon Pengantin putri ( dalam uapacara siraman) menggunakan nyamping kemben "bangun tulak', dengan komposisi warna 
dasar biru kehitam-hitaman dengan motif blumbangan warna putih. Motif Jumputan, tritik jenis ini memiliki makna simbolisme untuk menjauhkan dari sing alus (makluk halus) sing kasar (jahat), serta mendekatkan para leluhurnya untuk senantiasa melindungi hidupnya, agar pengantin terhindar dari mara bahaya, dan kelak hidupnya akan bahagia.

\section{DAFTAR PUSTAKA}

Buchari, S., 2005, Kebudayaan Jawa, Surakarta: Universitas Sebelas Maret Press.

Holt, C., (dalam Soedarsono). 2000.Art in Indonesia: Continuities and Change.Ithaca. New York: Cornell University Press

Kartosoedjono. 1950. Kitab Wali Sepuluh. Kediri: Bukhandel Tan Khoen Swie.

Lincoln, Y.S., Guba, E.G., 1985, Naturalistic Inquiry, Baverly Hill: Sage Publications.

M. Harjowirogo, 1979, Adat Istiadat Jawa, Bandung: Patma.

Mulder, N., 2006, Pribadi dan Masyarakat Jawa, Jakarta: Sinar Harapan.

Putri, Tiara Trisnani. 2017. Pengaruh Komposisi Zat Warna Dispersi Terhadap Hasil Jadi Jumputan Pada Kain Organdi Polyester. Jurnal Penelitian Busana dan Desain. Surabaya. UNES: https://journal.unesa.ac.id/index.php/jbd

Read, H., 1970, Education Through Art, London: University of California Press.

Saidin. 2004. Aspek Hukum Hak Kekayaan Intelektual (Intelectual Property Rights),Jakarta: PT Raja Grafindo Persada.

Sarwono. 2016. Batik Wonogiren (Kajian Estetika). Disertasi. Surakarta: Institut Seni Indonesia

Soedarmono, 1990, Dinamika Kultural Jumputam tritik Klasik Jawa, Sarasehan Kebudayaan, Surakarta: Taman Budaya Pengembangan Jumputam tritik dan Kerajinan.

Suseno, Franz Magnis. 2001. Etika Jawa: Sebuah Analisa Falsafi tentang Kebijaksanaan Hidup Jawa.Jakarta : PT. Gramedia.

Sutopo, H.B., 2000, Metodologi Penelitian Kualitatif, Surakarta: Universitas Sebelas Maret Press.

Tiknopranoto, (t.th.). Pawiwahan Agesang. Surakarta. 
Titisari, Bintan. Kahdar, Kahfiati. Intan Rizky Mutiaz, Intan R. 2014. Pengembangan Teknik Jahit Celup (Tritik) dengan Pola Geometris, Bandung: Jurnal Visual Art and Desain. vol. 6 , no. 2. 